\title{
A tribute: Professor Dr. Paul Hoffmann (March 28, 1931-July 10, 2008), a scientist with a great collaborative spirit
}

\author{
H. Lokstein · E. Höxtermann · D. Leupold · G. Garab · G. Renger
}

Received: 3 February 2009/Accepted: 18 February 2009/Published online: 10 March 2009

(C) Springer Science+Business Media B.V. 2009

Professor emeritus Dr. rer. nat. habil. Paul Hoffmann (see Fig. 1) passed away after a serious illness on July 10, 2008, at the age of 77. The scientific community, in the field of photosynthesis research and at the Humboldt-Universität zu Berlin (Humboldt University Berlin), has lost a dedicated researcher, teacher, and colleague.

Paul Hoffmann was born in Sattel, a small Silesian village near Grünberg (now Zielona Góra, Poland), in 1931, as the only son (he had four younger sisters) of a farmer and forestry worker. As a result of World War II, the family had to leave this region and migrated to Western Pomerania in 1945. Here, Paul Hoffmann attended a secondary school in Franzburg and passed the "Abitur" in 1951. In the same year he began to study biology at the University of Greifswald, one of the oldest universities in Germany, earlier focussing on botany, in particular, plant

\section{H. Lokstein}

Institut für Biochemie und Biologie/Pflanzenphysiologie, Universität Potsdam, Karl-Liebknecht-Str. 24-25, Haus 20, D-14476 Potsdam-Golm, Germany

E. Höxtermann

Am Gutshof 58, D-13059 Berlin, Germany

D. Leupold

LTB Lasertechnik Berlin GmbH, Rudower Chaussee 29, D-12489 Berlin, Germany

\section{G. Garab}

Biological Research Center, Temesvári krt. 62, H-6701 Szeged, Hungary

\section{G. Renger ( $\square)$}

Technische Universität Berlin, Institut für Chemie, Max-Volmer-Laboratorium für Biophysikalische Chemie, Straße des 17. Juni 135, D-10623 Berlin, Germany e-mail: Gernot.Renger@alumni.TU-Berlin.DE physiology. In 1956, he started his scientific career as an "Assistent" (scientific assistant) at the Botanical Institute, headed by the well-known plant physiologist Heinrich Borriss (1909-1985). At this time, he switched the field of his research activities from earlier electrophysiological studies on leaves of Elodea, the topic of his diploma thesis (completed in 1956), to problems related to photosynthesis. In 1960, he finished his doctoral thesis entitled "Studies on Photosynthesis and Respiration of Green Leaves of Different Ages", receiving his Dr. rer. nat. degree (equivalent to $\mathrm{PhD}$ ). The major findings of this research were published in the German journal "Flora" (Hoffmann 1962a, b). In 1961, Hoffmann was appointed as a "Senior Assistant" at the "Institut für Allgemeine Botanik" (Institute of General Botany) of Humboldt University in Berlin. He continued to focus his scientific efforts on the topics of photosynthesis and respiration in higher plants.

In 1966, Hoffmann obtained his "Habilitation" at the Humboldt University; this qualified him for a teaching position at a German University. The title of this work was "Physiology of Photosynthesis in Higher Plants" (Hoffmann 1968). He taught "General Botany" and "Photosynthesis" at the Humboldt University; here, he rose to the rank of a "Dozent" (lecturer) in 1967, becoming a full Professor in 1974. Hoffmann was a dedicated and a well-respected teacher. Following his motto "to demand and to promote", he not only encouraged, but also challenged undergraduate and graduate students in his lectures. As a leader of his growing research group, he applied the same standards to all of his co-workers. Hoffmann supervised about 80 diploma and about 20 doctoral theses-thus, establishing an influential East-German school of photosynthesis research. From 1978 to 1982, he headed the "Sektion Biologie" (Department of Biology) of the Humboldt University. 


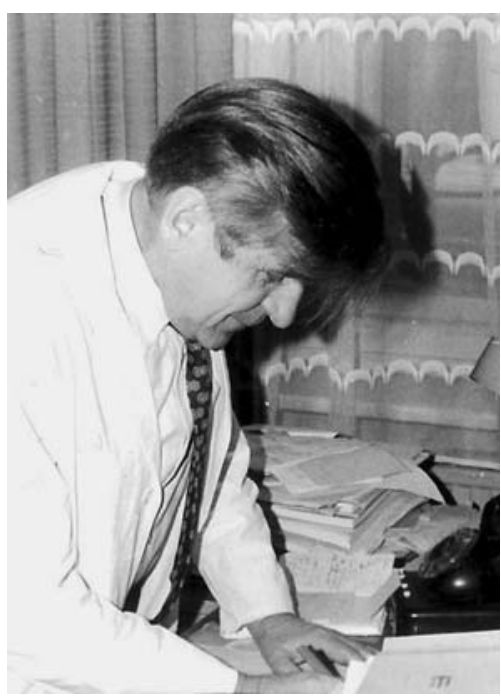

Fig. 1 Professor Paul Hoffmann in his office in 1988. Courtesy of E. Helmer

In addition to publishing an impressive number (about 150) of primary research and review papers in national and international scientific as well as in popular journals, he wrote a comprehensive paperback textbook on photosynthesis in German ("Photosynthese"), which was published by the Akademie-Verlag Berlin, in its first edition in 1975 (Hoffmann 1975). This monograph became a standard book for students and young researchers in the field of photophysics, physiology, and ecology of photosynthesis in Eastern Europe. The very positive "resonance" of the book, among its readers, led to a second (revised) edition (published in 1987). This revised edition was also translated (by Zoltan Szigeti) into Hungarian (Hoffmann 1987) and was used for many years in the university courses.

Hoffmann's broad and profound knowledge-far exceeding the field of his own special research activitiesenabled him to establish and promote interdisciplinary cooperation with experts of other fields of science. Of particular success was the highly innovative collaboration with laser physicists from the Central Institute of Optics and Spectroscopy of the East-German (GDR, German Democratic Republic) Academy of Sciences. The project, starting in the 1970s when lasers first became available as powerful tools for (photosynthesis) research purposes, was very productive. This is illustrated by a number of publications, for example, "Laser action and excited state absorption of chlorophyll $a$ " (Leupold et al. 1977), "Low intensity two step absorption of chlorophyll $a$ in vivo" (Leupold et al. 1978), and "Collective excitation and luminescence of chlorophyll in vivo" (Leupold et al. 1979). For the excellent results emerging from these interdisciplinary efforts, Paul Hoffmann and the associated team of physicists and mathematicians were awarded the highly prestigious Leibniz Prize (Leibniz-Preis) of the Academy of Sciences of the GDR in 1979.

Paul Hoffmann was well known for bringing together national and international researchers with multiple expertise. At home and among foreign colleagues, he had an excellent reputation. He paid special attention to the COMECON $^{1}$ Photosynthesis Research Conferences and Programs, which in the 1970s and 1980s provided virtually the only international forum for many 'Eastern Bloc' scientists and students. These meetings and programs, despite their relative isolation, were instrumental in maintaining photosynthesis research laboratories with international standards in these countries. Hoffmann, and his colleagues and friends, Alexander A. Krasnovsky (USSR), Andrey B. Rubin (USSR), Danuta Frąckowiak (Poland), Ágnes Faludi-Dániel (Hungary), Zoltan Szigeti (Hungary), Zdeněk Šesták (Czechoslovakia), Ivan Yordanov (Bulgaria) - to name just a few-never compromised for less and spared no effort to launch longstanding research collaboration and scientific exchange.

Paul Hoffmann's important role in these collaborative activities is illustrated by recollections of his colleagues and friends. Natalia Averina, Nikolai Shalygo, Galina Savchenko, and Elena Yaronskaya, from the Institute of Biophysics and Cell Engineering (former Institute of Photobiology), Academy of Sciences of Belarus, Minsk, wrote:

In 1969 Professor Dr. Alexander Shlyk, the then director of the Institute of Photobiology (Minsk, Belarus), and Professor Dr. Paul Hoffmann agreed to establish collaborative work in Minsk. The aim was to elucidate the role of kinetin in the biosynthesis of protochlorophyllide. A resulting first joint article was published in 1970 (Shlyk et al. 1970). At that time nobody could imagine that the collaboration would become very fruitful and last for long years. Over the years 25 joint scientific articles were published. We will always remember Professor Hoffmann talking with enthusiasm about problems of energetics in photosynthesis. Professor Hoffmann was a very hospitable person. He always promoted scientific collaboration and was very glad that the collaboration continued with his successor-Professor Bernhard Grimm.

A personal recollection of Prof. Dr. Danuta Wróbel, Institute of Physics, Poznan University of Technology, Poland, follows:

\footnotetext{
${ }^{1}$ COMECON stands for the Council of Mutual Economic Assistance; it was the East European economic organization, equivalent to the European Economic Community, and offered bilateral and multilateral scientific exchange programs and series of topical scientific meetings.
} 
For the first time I met Professor Hoffmann in Liblice (Czechoslovakia) in 1972 during a Symposium "Photosynthesis and Chlorophylls in vivo with Special Reference to Methods of Their Determination". I was very much interested in the physical processes in photosynthesis. Thus, I remember Professor Hoffmann's interesting lecture on pigment physiology in wheat seedlings very well. Later on, we met several times, e.g., in Germany and Hungary. Professor Hoffmann's lectures were very important for us. I remember his marvelous talk on "Primary processes of photosynthetic energy conversion in higher plants" and "Laser spectroscopic investigations on the $\mathrm{S}_{0}-\mathrm{S}_{1}$ subbands of chlorophyll $a$ in vivo". I am grateful to Professor Paul Hoffmann for inspiring me in my research work and teaching. I always tried to confer ideas of phenomena occurring in photosynthesis and to underline how human beings can follow nature to take advantage in our "ordinary" life, science and technology. Professor Paul Hoffmann was always kind, a smiling and a charming man, very open to other people. I will always remember him.

Hoffmann always encouraged the members of his research group to develop their own international cooperation. He also initiated fruitful collaboration and personal contacts among the authors of this obituary, which resulted in several joint publications (see e.g., Höxtermann et al. 1982, 1986; Lokstein et al. 1993, 1994, 1995). Based on his communicative competence combined with high scientific reputation, the "International Photosynthesis Workshops", which were organized by him and his team in the 1970s and 1980s, became important platforms for international scientific exchange between researchers from Eastern and Western Europe and helped to surmount political boundaries. Hoffmann also found means to establish links with research groups from the West.

Moreover, his personal commitment and his invaluable contact with many scientists were also beneficial for the establishment of the primary photosynthesis research journal "Photosynthetica" (Prague), in 1967, of which he was an editorial board member until his untimely death. (For a history of this journal, see Govindjee et al. 2002.)

Following the re-unification of Germany, the "Institut für Biologie" (Institute for Biology) at Humboldt University was entirely re-organized and Paul Hoffmann-due to his personal integrity and scientific reputation-was reappointed as a Professor in 1992; he then held the Chair of Plant Physiology.

Hoffmann's activities were not restricted to the university only. Together with a team of university and school teachers, he compiled a standard textbook for teaching biology in secondary schools (Hoffmann et al. 1996). After

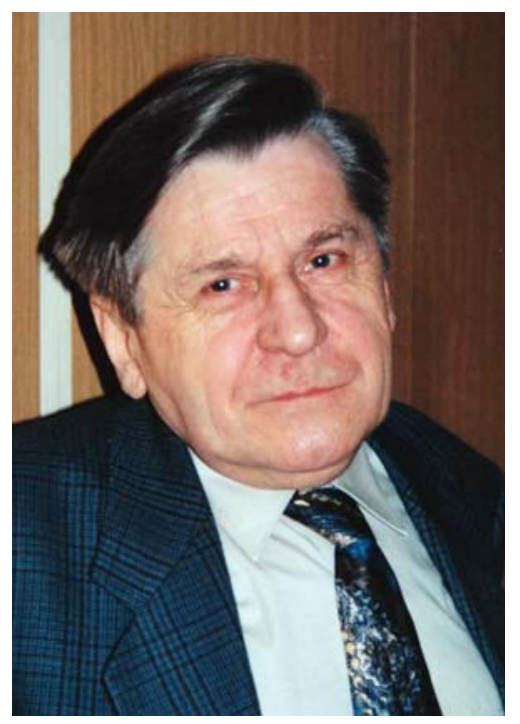

Fig. 2 Professor Paul Hoffmann on his 65th birthday, in 1996. Courtesy of E. Helmer

his retirement in 1996 (Fig. 2), he was succeeded by Bernhard Grimm, who now holds the Chair of Plant Physiology and continues research on physiological and molecular biological aspects of photosynthesis at the Humboldt University in Berlin.

Paul Hoffmann was one of the initiators of the highly successful Berlin-Potsdam area "Sonderforschungsbereich" (SFB, Collaborative Research Center) 429 "Molecular Physiology, Energetics and Regulation of Plant Primary Metabolic Processes". As an emeritus professor, he not only continued research but also kept a strong interest in more general implications of the evolution of our society, our planet and the universe (see, e.g., Hoffmann 1998). He was - in the best sense - a traditional educated scholar with high ethical standards and had a deep feeling for the responsibility of scientists to protect and preserve life on earth.

Paul Hoffmann is survived by his wife and two daughters.

We will remember him as a highly esteemed teacher and supervisor, organizer, prolific researcher and a dear colleague. The "Sonderforschungsbereich" 429 will hold a commemorative colloquium to honor Professor Dr. Paul Hoffmann in 2009.

We end this tribute by showing three pictures of Paul Hoffmann interacting with several colleagues. Figures 3 and 4 are pictures taken at the "German-Belarus Symposium on Biophysics of Photosynthesis", Egsdorf, Germany, 2003 - probably the last international meeting that Hoffmann attended. Figure 5 shows a photograph of Hoffmann together with other scientists after Govindjee delivered a lecture at the Humboldt University in 2006. 
Fig. 3 Professor Paul Hoffmann (third from left) among the participants of the "German-Belarus Symposium on Biophysics of

Photosynthesis," Egsdorf,

Germany, 2003. Other participants included: Vladimir Shuvalov, Olga Kaminskaya, Vyacheslav Klimov, Elena Yaronskaya, Wolfhard Rüdiger, Nikolai Shalygo, Natalia Averina, Igor Volotovski, Hugo Scheer, Bernhard Grimm, Peter Jahns, Ljudmilla Kalituho, Carsten Tietz, Gernot Renger, Harald Paulsen, Heiko Lokstein, and Dieter Leupold

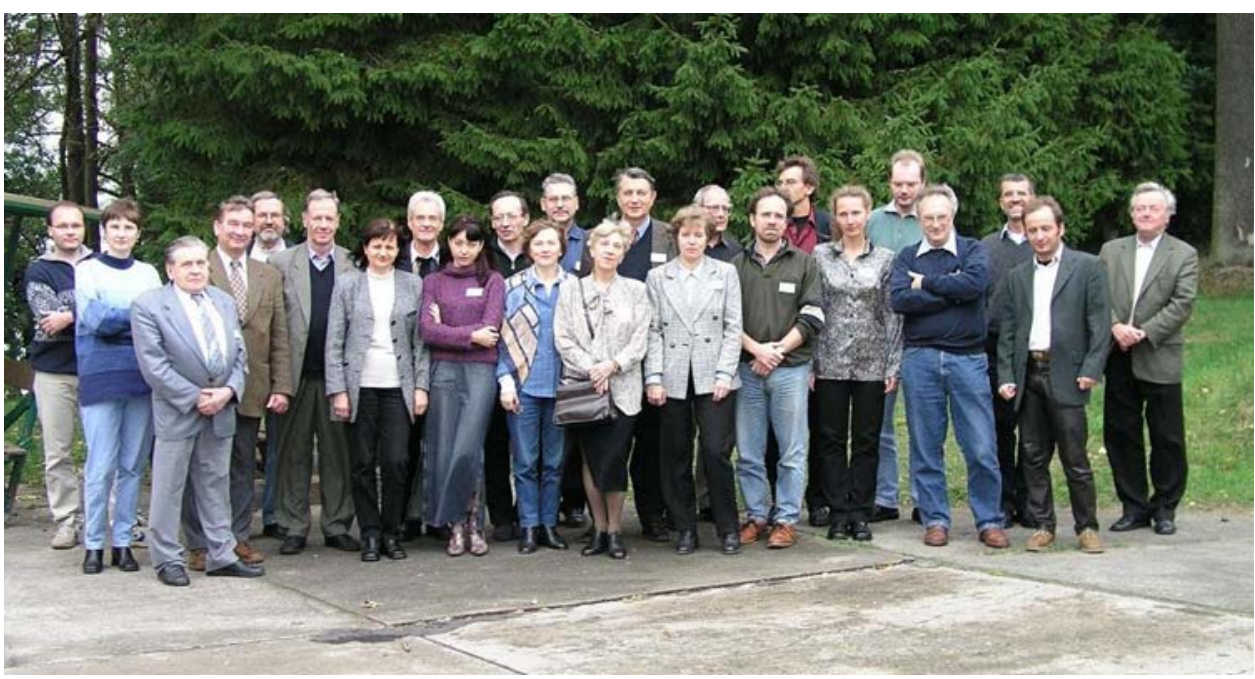

Acknowledgment We thank Govindjee for editing this manuscript.

\section{References}

Govindjee, Šesták Z, Peters WR (2002) The early history of "Photosynthetica", "Photosynthesis research", and their publishers. Photosynthetica 40:1-11. doi:10.1023/A:1020169502548

Hoffmann P (1962a) Untersuchungen über Photosynthese und Atmung von Laubblättern verschiedenen Alters. Flora 152: 622-654 (in German)

Hoffmann P (1962b) Der Einfluß von Wirkstoffen auf die Photosynthese und Atmung alternder Laubblätter. Flora 152:702-706 (in German)

Hoffmann P (1968) Zur Physiologie der Photosynthese bei höheren Pflanzen. Botanische Studien, Jena. 18:151 (in German)

Hoffmann P (1975) Photosynthese (in German). WTB 158, Akademie-Verlag, Berlin

Hoffmann P (1987) Fotoszintézis (translated to Hungarian by Z. Szigeti). Mezőgazdasági Kiadó, Budapest, p 249

Hoffmann P (1998) Oxygenic photosynthesis-a photon driven hydrogen generator-the energetic/entropic basis of life. Photosynthetica 35:1-11. doi:10.1023/A:1006872110196

Hoffmann P, Knobloch D, Kämpfe L, Meißner K, Schenke G, Schöneich J, Schröder H, Sedlag U, Heinrich D in co-operation with Gemeinhardt H-D, Heinzel K, König I, Schleicher S (1996) Biologie. Lehrbuch für Sekundarstufe II (in German). Volk und Wissen Verlag, Berlin, p 376

Höxtermann E, Werncke W, Stadnichuk IN, Lau A, Hoffmann P (1982) Resonance coherent anti-Stokes Raman scattering (CARS) of chlorophyll. I-III. Stud Biophys 92:147-175

Höxtermann E, Werncke W, Tschö JT, Brecht E, Lau A, Hoffmann P (1986) Resonance coherent anti-Stokes Raman scattering (CARS) of chlorophyll. IV-V. Stud Biophys 113:165-170, 115:85-94

Leupold D, Mory S, Hoffmann P, Hieke B, König R (1977) Laser action and excited state absorption of chlorophyll $a$. Chem Phys Lett 45:567-571. doi:10.1016/0009-2614(77)80091-2

Leupold D, Voigt B, Mory S, Hoffmann P, Hieke B (1978) Low intensity two step absorption of chlorophyll $a$ in vivo. Biophys $\mathrm{J}$ 21:177-180. doi:10.1016/S0006-3495(78)85517-9

Leupold D, Voigt B, Hoffmann P (1979) Collective excitation and luminescence of chlorophyll in vivo. Proc. III Conf Lumin II:343-354 
Lokstein H, Härtel H, Hoffmann P, Renger G (1993) Comparison of chlorophyll fluorescence quenching in leaves of wild-type with a chlorophyll- $b$-less mutant of barley (Hordeum vulgare L.). J Photochem Photobiol B. Biol 19:217-225

Lokstein H, Härtel H, Hoffmann P, Woitke P, Renger G (1994) The role of light-harvesting complex II in excess excitation dissipation: an in vivo fluorescence study on the origin of high-energy quenching. J Photochem Photobiol B. Biol 26: $175-184$
Lokstein H, Leupold D, Voigt B, Nowak F, Ehlert J, Hoffmann P, Garab G (1995) Nonlinear polarization spectroscopy in the frequency domain of light-harvesting complex II: absorption band substructure and exciton dynamics. Biophys J 69:15361543. doi:10.1016/S0006-3495(95)80025-1

Shlyk AA, Walter G, Averina NG, Savchenko GE (1970) Effect of kinetin on the biosynthesis of active protochlorophyllide in green and post-etiolated leaves of wheat. Dokl Akad Nauk SSSR 193:1429-1432 (in Russian) 